\title{
PENGARUH SHORT MESSAGE SERVICE TERHADAP KEPATUHAN PENGOBATAN DAN GAYA HIDUP PASIEN DIABETES MELITUS DI RSUD DR. M. ASHARI PEMALANG
}

\author{
EFFECT OF SHORT MESSAGE SERVICE TOWARDS \\ MEDICATION ADHERENCE AND LIFESTYLE OF DIABETES \\ MELLITUS PATIENT IN RSUD DR. M. ASHARI PEMALANG
}

\author{
Pradnya Aulia Rahmah, Githa Fungie Galistiani, Anjar Mahardian Kusuma \\ Fakultas Farmasi, Universitas Muhammadiyah Purwokerto \\ E-mail: pradnyarahmah@gmail.com
}

\begin{abstract}
ABSTRAK
Keberhasilan terapi diabetes dipengaruhi oleh pengobatan dan gaya hidup pasien. Ketidakpatuhan menjadi salah satu penyebab dari hasil pengobatan yang buruk, berkembangnya gejala penyakit, serta komplikasi. Perlu adanya perlakuan untuk mencapai hasil terapi yang optimal, salah satunya dengan pemberian Short Message Service (SMS) terkait pengobatan diabetes dan gaya hidup yang baik. Penelitian ini bertujuan untuk mengetahui pengaruh SMS terhadap kepatuhan pengobatan dan gaya hidup pasien diabetes melitus di RSUD dr. M. Ashari Pemalang. Jenis penelitian ini adalah kuasi eksperimental dengan metode pengambilan sampel accidental sampling. Kepatuhan pengobatan diukur dengan kuesioner Medical Prescription Knowledge (MPK) sedangkan gaya hidup dinilai dengan kuesioner Summary of Diabetes Self care Activities (SDSCA). Responden yang berjumlah 81 orang dikelompokan menjadi kelompok kontrol dan intervensi. Sejumlah 41 responden kelompok intervensi diberikan perlakuan berupa SMS untuk mengonsumsi obat diabetes, serta anjuran untuk mematuhi pengobatan dan menjalankan gaya hidup yang baik. Sebanyak 40 pasien dalam kelompok kontrol tidak menerima SMS selama penelitian. Kepatuhan dan gaya hidup diukur sebelum dan setelah perlakuan. Pada penilaian gaya hidup terdapat pengaruh SMS yang diberikan, dilihat dari signifikansi perbedaan skor yang diperoleh pasien pada kedua kelompok. Pada variabel kepatuhan pengobatan belum terdapat pengaruh dari SMS yang diberikan selama penelitian.
\end{abstract}

Kata kunci: Diabetes, kepatuhan pengobatan, gaya hidup, SMS 


\section{ABSTRACT}

The success of diabetes management is influenced by treatment and patient's lifestyle. Poor medication adherence becomes one of the causes of poor treatment outcomes, development of disease symptoms, and complications. Intervention is needed to achieve optimal outcomes, one of which is the provision of Short Message Service (SMS) related to the treatment of diabetes and a good lifestyle. The objective of the study was to determine the impact of SMS on medication adherence and lifestyle in diabetes mellitus patients in RSUD dr. M. Ashari Pemalang. This research was quasi experimental with accidental sampling method. Medication adherence was measured by Medical Prescription Knowledge questionnaire, while lifestyle by Summary of Diabetes Selfcare Activities. From 81 respondents, 41 respondents were grouped into intervention group and received SMS for taking medications regularly, as well as advice to comply with treatment and running good lifestyles. While 40 patients in the control group did not receive the message during the study. Measurement was done before and after intervention. Analysis result showed that SMS intervention has impact on lifestyle assessment, seen from the significant difference of the scores in both groups. Meanwhile, SMS given during the study has not influenced patient's medication adherence yet.

Keywords: Diabetes, medication adherence, lifestyle, SMS

\section{PENDAHULUAN}

Diabetes merupakan penyakit dengan kasus kejadian yang tersebar luas di seluruh dunia (Chan et al, 2005). Menurut International Diabetes Federation atau IDF (2014) dalam Diabetes Atlas sixth edition, jumlah penduduk dunia usia 20-79 tahun yang menderita diabetes pada tahun 2014 adalah 387 juta jiwa, dengan 9,1 juta jiwa diantaranya merupakan penduduk Indonesia.

Tidak semua pasien diabetes mematuhi pengobatan yang diterimanya. Berdasarkan referensi, jumlah pasien yang patuh terhadap pengobatannya hanya berkisar antara 60-65\% (Briesacher et al, 2008 ; Jha et al, 2012). Ketidakpatuhan tersebut menjadi penyebab dari perburukan gejala yang dapat mengakibatkan terjadinya komplikasi (DiMatteo, 2002).

Selain pengobatan, gaya hidup juga berperan penting dalam pengelolaan diabetes. Makanan yang dianjurkan bagi pasien diabetes hampir sama dengan masyarakat umum, hanya lebih diperhatikan pada jadwal, jenis, dan jumlah 
(Perkeni, 2011). Pasien diabetes juga perlu berolahraga untuk menurunkan dan menjaga kadar gula darah (Depkes, 2005). Olahraga yang dapat dilakukan yaitu jalan kaki, sepeda santai, jogging, dan berenang (Perkeni, 2011). Untuk meningkatkan kepatuhan pengobatan serta perilaku gaya hidup sehat, diperlukan suatu perlakuan terhadap pasien untuk mencapai tujuan pengobatan yang lebih optimal, terlebih pada zaman modern ini mayoritas pasien sudah memiliki Gadget yang dapat dimanfaatkan untuk meningkatkan kepatuhan pasien salah satunya dengan Short Message Service (SMS).

\section{METODE PENELITIAN}

Penelitian ini dilaksanakan di Poliklinik Penyakit Dalam Rumah Sakit Umum dr. M. Ashari Pemalang sejak akhir bulan Februari hingga akhir bulan Mei. Tahapan dalam penelitian ini meliputi uji validitas dan reliabilitas instrumen, pengambilan data pretest, pemberian perlakuan, dan pengambilan data posttest. Uji validitas dan reliabilitas dilaksanakan di dua rumah sakit yaitu Rumah Sakit Prima Medika Pemalang dan Rumah Sakit Islam Moga.

Penelitian ini merupakan penelitian kuasi eksperimental dimana terdapat intervensi atau perlakuan yang diberikan kepada responden penelitian. Perlakuan tersebut adalah SMS berisi pengingat minum obat diabetes, anjuran untuk patuh terhadap pengobatan, serta anjuran untuk menjalankan gaya hidup yang baik. SMS tersebut dikirimkan tiap 3 hari selama 30 hari. Sebelum diberi perlakuan terlebih dulu diukur kepatuhan pengobatan dan gaya hidup, begitu pula saat setelah perlakuan. Kemudian dari data hasil pengukuran tersebut dianalisis untuk mengetahui pengaruh SMS yang diberikan terhadap kepatuhan pengobatan dan gaya hidup responden.

Instrumen yang digunakan untuk mengukur kepatuhan pengobatan adalah kuesioner Medical Prescription Knowledge (MPK) (Prado-Aguilar, 2009), sedangkan gaya hidup dinilai dengan kuesioner Summary of Diabetes Self care Activities (SDSCA) (Toobert, 2000). Kuesioner MPK terdiri dari 2 aspek penilaian yaitu aspek sikap dan pengetahuan. Pada aspek sikap terdapat 11 item pernyataan dengan pilihan jawaban sangat setuju, setuju, netral, tidak setuju, dan 
tidak setuju. Item pernyataan pada aspek sikap meliputi pendapat pasien mengenai kenyamanan dalam penggunaan obat, kepercayaan tentang kerusakan akibat obat, hubungan antara pengobatan diabetes dan komplikasi, pendukung dan penghambat kepatuhan, kemudahan akses terhadap pengobatan, dan persetujuan dokter-pasien terhadap pengobatan. Pada aspek pengetahuan terdapat 3 pertanyaan mengenai nama obat diabetes yang digunakan, jumlah obat tiap kali minum, dan frekuensi minum obat tiap hari. Kuesioner MPK menurut PradoAguilar (2009) mengungkapkan bahwa pasien dikategorikan patuh bila rata-rata skor aspek sikap 4-5 dan total aspek pengetahuan 3, serta dikategorikan tidak patuh bila rata-rata skor aspek sikap yang diperoleh 1-3 dan pengetahuan $<3$. Untuk memudahkan penilaian pada responden dengan rata-rata skor sikap 3-4 dalam penelitian ini responden dinyatakan patuh bila mendapat rata-rata skor sikap > 3 dan total skor pengetahuan 3 .

Variabel gaya hidup diukur dengan kuesioner Summary of Diabetes Selfcare Activities yang merupakan hasil penelitian dari Toobert. Kuesioner SDSCA yang diacu pada penelitian ini adalah kuesioner modifikasi oleh Sulistria (2013). SDSCA tersebut terdiri dari 13 item pertanyaan yang menilai aktivitas pasien terkait gaya hidup sehat pada pasien diabetes, meliputi penilaian pola makan, aktivitas tubuh, pengobatan, dan perawatan kaki. Penilaian yang digunakan adalah skor dimana semakin tinggi skor mengindikasikan gaya hidup pasien diabetes yang lebih baik.

Jumlah sampel minimal dalam penelitian ini adalah 82 yang terdiri dari 41 responden kelompok kontrol dan 41 responden kelompok intervensi. Pasien yang dilibatkan dalam penelitian adalah pasien diabetes yang berobat rawat jalan di RSUD dr. M. Ashari yang memenuhi kriteria. Adapun kriteria inklusi dalam penelitian ini adalah pasien diabetes melitus tanpa penyakit penyerta berusia $\geq 40$ tahun, menjalankan rawat jalan sekurang-kurangnya 1 tahun, mendapatkan antihiperglikemik oral tanpa insulin, memiliki handphone pribadi dan dapat mengoperasikannya, dan bersedia menjadi responden. Kriteria eksklusi dalam penelitian ini adalah wanita hamil, sedang belajar atau bekerja di bidang kesehatan, pasien yang beralamat di luar kabupaten Pemalang, pasien yang sukar 
ditemui, pasien yang mengalami hambatan komunikasi saat penelitian, serta pasien yang mendapat penggantian terapi selama masa penelitian. Data yang diperoleh selanjutnya dianalisis univariat untuk mendeskripsikan karakteristik responden penelitian dan analisis bivariat untuk menganalisis variabel yang berkaitan atau berhubungan (Notoatmodjo, 2010).

\section{HASIL DAN PEMBAHASAN}

Uji validitas dan reliabilitas kuesioner dilakukan di rumah sakit yang berbeda dengan tempat penelitian. Dalam uji ini melibatkan sejumlah pasien diabetes yang memenuhi kriteria yang melakukan rawat jalan di Rumah Sakit Prima Medika Pemalang dan Rumah Sakit Islam Moga berturut-turut sebanyak 20 dan 10 pasien. Uji ini dilaksanakan sejak 22 Februari sampai 26 Maret 2016. Setelah 30 kuesioner terisi kemudian dilakukan analisis data untuk mengetahui validitas dan reliabilitas kuesioner. Hasil analisis tersebut menunjukan nilai $r$ hitung yang lebih besar dari $\mathrm{r}$ tabel untuk 30 responden. Oleh karena itu kuesioner dinyatakan valid. Nilai $\alpha$ yang didapatkan lebih besar dari 0,6 sehingga kuesioner dinyatakan reliabel.

Selama satu bulan dilakukan pengambilan data pretest, tidak semua pasien diabetes yang ditemui di rumah sakit memenuhi kriteria untuk menjadi responden, baik karena penggunaan kombinasi obat oral dan insulin, tidak memiliki handphone pribadi, maupun tidak bersedia menjadi responden penelitian. Pasien yang tidak bersedia menjadi responden mengaku keberatan apabila harus mengisi kuesioner dan menerima SMS selama 30 hari tersebut. Oleh karena itu didapatkan 84 responden yang terdiri dari 42 responden kelompok kontrol dan 42 responden kelompok intervensi. Namun di tengah proses penelitian terdapat 1 responden kelompok intervensi dan 2 responden kelompok kontrol yang keluar dari penelitian karena sukar ditemui pada saat pengambilan data posttest, sehingga jumlah responden menjadi 81 yang terdiri dari 40 responden kontrol dan 41 intervensi. Dari 81 responden tersebut dilakukan analisis pada karakteristiknya seperti yang ditunjukan pada Tabel I. 
Tabel I. Karakteristik responden penelitian

\begin{tabular}{lcc}
\hline & \multicolumn{2}{c}{ Jumlah Responden } \\
\cline { 2 - 3 } Karakteristik Responden & $\begin{array}{c}\text { Kelompok Kontrol } \\
(\mathbf{n = 4 0 )}\end{array}$ & $\begin{array}{c}\text { Kelompok Intervensi } \\
(\mathbf{n}=\mathbf{4 1})\end{array}$ \\
\hline Umur (Mean \pm SD) & $59,12 \pm 8,131$ & $59,17 \pm 7,389$ \\
\hline Jenis Kelamin & & \\
Laki-laki & $21(52,5 \%)$ & $24(58,5 \%)$ \\
Perempuan & $19(47,5 \%)$ & $17(41,5 \%)$ \\
\hline Pekerjaan & & \\
PNS & $7(17,5 \%)$ & $8(19,5 \%)$ \\
Pekerja Informal & $10(25,0 \%)$ & $8(19,5 \%)$ \\
Tidak Bekerja & $23(57,5 \%)$ & $25(61 \%)$ \\
\hline Pendidikan & & \\
SD & $4(10,0 \%)$ & $3(7,3 \%)$ \\
SMP dan SMA & $28(70,0 \%)$ & $25(61,0 \%)$ \\
Akademi dan PT & $8(20,0 \%)$ & $13(31,7 \%)$ \\
\hline Jumlah obat & & \\
1 & $3(7,5 \%)$ & $2(4,9 \%)$ \\
2 & $28(70,0 \%)$ & $33(80,5 \%)$ \\
3 & $8(20,0 \%)$ & $5(12,2 \%)$ \\
4 & $0(0 \%)$ & $1(2,4 \%)$ \\
5 & $1(2,5 \%)$ & $0(0 \%)$ \\
\hline
\end{tabular}

Kepatuhan Pengobatan

Sikap merupakan suatu kecenderungan berperilaku. Sikap mencerminkan perasaan seseorang terhadap suatu obyek, yang direspons dengan suatu pernyataan evaluatif (Budiman, 2013). Menurut Notoatmodjo dalam Budiman (2013), pengetahuan adalah hasil dari tahu, yang diperoleh setelah proses pengindraan terhadap objek. Dalam kuesioner MPK yang digunakan, kedua aspek ini berperan dalam penentuan kepatuhan. Berikut data rata-rata skor aspek sikap dan pengetahuan yang diperoleh responden penelitian kelompok kontrol dan intervensi sebelum dan setelah perlakuan.

Tabel II. Perbandingan Skor Aspek Sikap dan Pengetahuan Masing-Masing Kelompok

\begin{tabular}{lcccccc}
\hline \multirow{2}{*}{ Kelompok } & \multicolumn{2}{c}{ Sikap } & & \multicolumn{2}{c}{ Pengetahuan } & \multirow{2}{*}{ P } \\
\cline { 2 - 3 } & $\begin{array}{c}\text { Sebelum } \\
\text { perlakuan }\end{array}$ & $\begin{array}{c}\text { Setelah } \\
\text { perlakuan }\end{array}$ & P value & $\begin{array}{c}\text { Sebelum } \\
\text { perlakuan }\end{array}$ & $\begin{array}{c}\text { Setelah } \\
\text { perlakuan }\end{array}$ & \\
\hline value \\
\hline Kontrol & 3,568 & 3,559 & 0,506 & 86 & 87 & 0,564 \\
Intervensi & 3,738 & 3,918 & 0,000 & 89 & 99 & 0,007 \\
\hline
\end{tabular}


Berdasarkan tabel II, pada kelompok kontrol rata-rata skor aspek sikap yang diperoleh sebelum perlakuan adalah 3,568. Pada pengukuran yang kedua, rata-rata skor menjadi 3,559 dengan $p$ value 0,506 yang menunjukan tidak adanya perbedaan yang signifikan pada skor aspek sikap kelompok kontrol sebelum dan setelah perlakuan. Pada kelompok intervensi terjadi peningkatan skor aspek sikap yang diperoleh, dengan $p$ value 0,000 . Nilai $\mathrm{p}$ ini menunjukan adanya perbedaan signifikan pada aspek sikap kelompok intervensi sebelum dan setelah perlakuan.

Pada aspek kepatuhan, skor total responden kelompok kontrol mengalami peningkatan dari $86 \mathrm{ke} 87$, namun p value yang ditunjukan adalah 0,564 sehingga dinyatakan bahwa perubahan tersebut tidak bermakna. Kelompok intervensi mengalami peningkatan skor dari 89 ke 99 dengan $p$ value 0,007 yang menunjukan adanya perbedaan yang signifikan pada aspek pengetahuan kelompok intervensi sebelum dan setelah perlakuan.

Berdasarkan jawaban responden terhadap kuesioner kepatuhan dapat dikategorikan pasien patuh atau tidak terhadap pengobatan diabetes yang diterimanya sesuai dengan panduan skoring yang ditentukan. Perbandingan kepatuhan pengobatan sebelum dan setelah perlakuan antara kelompok kontrol dan kelompok intervensi tertera pada Tabel III.

Tabel III. Perbandingan Kepatuhan Sebelum dan Setelah Perlakuan pada Kelompok Kontrol dan Intervensi

\begin{tabular}{cccccc}
\hline \multirow{2}{*}{ Kelompok } & \multicolumn{2}{c}{ Sebelum perlakuan } & \multicolumn{2}{c}{ Setelah perlakuan } & \multirow{2}{*}{ P Value } \\
\cline { 2 - 5 } & Patuh & Tidak Patuh & Patuh & Tidak Patuh & \\
\hline Kontrol & 7 & 33 & 8 & 32 & 1,000 \\
Intervensi & 12 & 29 & 17 & 24 & 0,062 \\
\hline
\end{tabular}

Setelah dikategorikan menjadi patuh dan tidak patuh, untuk masing-masing kelompok baik pada kelompok kontrol maupun intervensi, tidak terdapat perbedaan kepatuhan yang signifikan pada saat sebelum dan setelah perlakuan. Hasil analisis antar kelompok ditunjukan pada Tabel IV. $P$ value yang diperoleh menunjukan adanya perbedaan kepatuhan antara kelompok kontrol dan kelompok intervensi, baik pada saat sebelum maupun setelah diberikannya perlakuan. Hal 
ini berarti perbedaan tersebut telah ada pada saat sebelum penelitian ini dilaksanakan.

Tabel IV. Perbandingan Kepatuhan antar Kelompok Sebelum dan Setelah Perlakuan

\begin{tabular}{ccccc}
\hline \multirow{2}{*}{ Kelompok } & \multicolumn{2}{c}{ Pretest } & \multicolumn{2}{c}{ Posttest } \\
\cline { 2 - 5 } & Jumlah & P value & Jumlah & P value \\
\hline Kontrol & 7 & 0,030 & 8 & 0,037 \\
Intervensi & 12 & & 17 & 0 \\
\hline
\end{tabular}

\section{Gaya Hidup}

Kuesioner yang digunakan untuk menilai gaya hidup dalam penelitian ini didapatkan data dalam bentuk numerik, kemudian dihitung selisih skor yang diperoleh responden saat pengukuran gaya hidup yang pertama dengan pengukuran yang kedua. Dari data tersebut dapat disimpulkan terdapat perbedaan yang signifikan atau tidak antara gaya hidup sebelum dan sesudah perlakuan SMS.

Tabel V. Perbandingan gaya hidup sebelum dan setelah perlakuan masing-masing kelompok

\begin{tabular}{cccc}
\hline \multirow{2}{*}{ Kelompok } & Sebelum perlakuan & Setelah perlakuan & \multirow{2}{*}{ P Value } \\
\cline { 2 - 3 } & Mean & Mean & \\
\hline Kontrol & 50,62 & 51,02 & $0,808^{*}$ \\
Intervensi & 51,54 & 62,68 & $0,000^{*}$ \\
\hline
\end{tabular}

Berdasarkan tabel $\mathrm{V}$, pada kelompok kontrol $p$ value yang diperoleh adalah 0,808 yang menunjukan tidak adanya perbedaan yang signifikan pada skor gaya hidup sebelum dan setelah perlakuan. Pada kelompok intevensi, $p$ value 0,000 menyatakan adanya perbedaan yang bermakna pada skor gaya hidup yang diperoleh sebelum dan setelah perlakuan. Ketika dilakukan analisis antar kelompok, terdapat perbedaan signifikan pada skor gaya hidup sebelum dan setelah perlakuan pada kelompok kontrol dan kelompok intervensi, seperti yang ditunjukan dalam Tabel VI. 
Tabel VI. Perbandingan gaya hidup kelompok kontrol dan intervensi

\begin{tabular}{ccc}
\hline Kelompok & Jumlah selisih skor & P value \\
\hline Kontrol & 14 & 0,000 \\
Intervensi & 457 & \\
\hline
\end{tabular}

Pada variabel kepatuhan pengobatan dari penelitian ini diperoleh data berupa skor aspek sikap dan skor aspek pengetahuan yang merupakan komponen dari kuesioner kepatuhan yang digunakan. Hasil analisis menunjukan adanya perbedaan skor antara kelompok kontrol dan kelompok intervensi baik pada aspek sikap maupun aspek pengetahuan. Pada saat dianalisis tiap kelompok, tidak terdapat perbedaan signifikan pada aspek sikap dan pengetahuan kelompok kontrol sebelum dan setelah perlakuan. Sementara pada kelompok intervensi, terdapat perbedaan signifikan pada aspek sikap dan aspek pengetahuan. Namun setelah dikategorikan menjadi patuh dan tidak patuh, tidak terdapat perbedaan yang signifikan baik pada pretest maupun posttest kelompok kontrol, serta pretest dan posttest kelompok intervensi. Antara hasil posttest kelompok kontrol dan kelompok intervensi terdapat perbedaan yang signifikan. Namun saat sebelum diberikan perlakuan, hasil pretest kelompok kontrol dan intervensi pun menunjukan perbedaan yang signifikan pula. Oleh karena itu, perbedaan kepatuhan setelah perlakuan tersebut sudah ada sebelum perlakuan diberikan. Hasil analisis menunjukan bahwa terdapat perbedaan yang signifikan pada aspek sikap dan pengetahuan saat sebelum dan setelah perlakuan. Hal ini menunjukkan bahwa perlakuan SMS yang diberikan berpengaruh terhadap sikap dan pengetahuan yang merupakan bagian dari kuesioner yang digunakan untuk mengukur kepatuhan pasien diabetes melitus dalam penelitian ini. Tidak adanya perbedaan yang signifikan pada kepatuhan setelah dikategorikan mungkin terjadi karena jumlah responden yang mengalami peningkatan pada keduanya tidak signifikan sehingga tidak menunjukan perbedaan setelah dikategorikan menjadi patuh dan tidak patuh. 
Hasil penelitian Zolfaghari et al (2012) menyatakan bahwa terdapat perbedaan kepatuhan yang signifikan antara sebelum perlakuan dan setelah perlakuan pada pasien diabetes yang diberi intervensi berupa SMS. Huang et al (2013) dalam penelitiannya juga menyatakan bahwa kepatuhan pasien dalam meminum obat meningkat setelah diberi SMS selama tujuh hari. Penelitian Alfian (2014) juga menunjukan bahwa terdapat pengaruh dari SMS yang diberikan farmasis terhadap kepatuhan pasien hipertensi yang menjadi responden dalam penelitiannya.

Intervensi yang diberikan pada penelitian ini adalah SMS yang dikirimkan tiap tiga hari sekali selama 30 hari, sehingga secara keseluruhan tiap responden menerima 10 SMS. Dalam satu SMS yang dikirimkan jumlah karakter tidak lebih dari 160 sehingga tidak dapat mencakup semua aspek yang diperlukan. Menurut Budiman (2013) salah satu faktor yang mempengaruhi sikap adalah pengaruh orang lain yang dianggap penting. Tidak adanya hubungan dekat antara responden dan pemberi SMS memungkinkan responden tidak bersikap seperti yang disarankan karena pemberi SMS bukan orang yang dianggap penting.

Kepatuhan pasien diabetes pada penelitian ini tidak hanya ditentukan oleh skor pada aspek sikap saja tetapi juga pengetahuan. Pada aspek pengetahuan responden dianjurkan untuk mengingat nama obat diabetes yang digunakan. Mayoritas responden tidak dapat menyebutkan nama obat diabetes yang diterimanya.

Dalam penelitian ini, rata-rata responden berusia 59 tahun. Berdasarkan kategori umur menurut Depkes (2009), usia 59 tahun termasuk ke dalam kategori lansia akhir (56 - 65 tahun). Budiman (2013) menyatakan bahwa usia berpengaruh terhadap daya tangkap dan pola pikir seseorang. Fisik atau mental pada orang yang berusia lanjut mengalami kemunduran, yang berakibat pada turunnya kemampuan seseorang seperti pada kosa kata dan pengetahuan umum.

Pada variabel gaya hidup terdapat perbedaan skor yang signifikan pada kelompok kontrol dan intervensi. Saat dianalisis masing-masing kelompok, perbedaan signifikan sebelum dan setelah perlakuan hanya terjadi pada kelompok intervensi, sementara pada kelompok kontrol tidak ada perbedaan skor gaya hidup 
yang bermakna. Hal ini menunjukan adanya pengaruh dari SMS yang diberikan terhadap gaya hidup pasien diabetes yang menjadi responden penelitian. Hal ini menunjukkan hasil yang sama dengan penelitian yang dilakukan oleh Zolfaghari et al (2012) yang menyebutkan bahwa terdapat perbedaan bermakna pada kepatuhan diet dan olahraga pasien yang menerima perlakuan SMS. Penelitian Kim et al (2006) juga menyatakan bahwa terdapat perbedaan bermakna pada aktivitas fisik pasien diabetes yang diberi SMS.

\section{KESIMPULAN}

Perlakuan SMS memberikan pengaruh terhadap gaya hidup pada pasien diabetes melitus, serta pada aspek sikap dan pengetahuan yang merupakan komponen dari kepatuhan dalam penelitian ini. Namun setelah dikategorikan menjadi patuh dan tidak patuh, SMS belum memberikan pengaruh yang signifikan.

\section{UCAPAN TERIMA KASIH}

Penulis mengucapkan terima kasih kepada pihak RSUD dr. M. Ashari Pemalang, Rumah Sakit Prima Medika Pemalang, Rumah Sakit Islam Moga, serta kepada semua pihak yang telah membantu penelitian.

\section{DAFTAR PUSTAKA}

Alfian, 2014, Layanan Pesan Singkat Pengingat untuk Meningkatkan Kepatuhan dan Menurunkan Tekanan Darah Pasien Hipertensi di RSUD dr. H. Moch Ansari Saleh Banjarmasin, Media Farmasi, 11 (2) : 189-196.

Briesacher, 2008, Comparison of Drug Adherence Rates Among Patients with Seven Different Medical Conditions, Pharmacoterapy, 28 (4) : 437-443.

Budiman, Riyanto, Agus, 2013, Kapita Selekta Kuesioner : Pengetahuan dan Sikap dalam Penelitian Kesehatan, Salemba Medika, Jakarta.

Chan, W.M., Woo, J., Hui, E., Lau, W.W., Lai J.C., Lee, D., 2005, A Community Model for Care of Elderly People with Diabetes via Telemedicine, Applied Nursing Research, 18 : 77-81. 
Departemen Kesehatan RI Direktorat Bina Farmasi Komunitas dan Klinik Direktorat Jenderal Bina Kefarmasian dan Alat Kesehatan., 2005, Pharmaceutical Care untuk Penyakit Diabetes Melitus, Depkes RI, Jakarta.

DiMatteo, 2004, Variations in Patients' Adherence to Medical Recommendations : a Quantitative Review of 50 Years of Research, Med Care, 42 : 200-209.

Huang, Li Yc, Chou Yc, Hsieh Yw, Kuo F, Tsai Wc, Chai Sd, Lin By, Kung Pt, Chuang Cj., 2013, Effects of and Satisfaction with Short Message Service Reminders for Patient Medication Adherene : a Randomized Controlled Study, BMC Medical Informatics and Decision Making, 13 (127) : 1-12.

International Diabetes Federation., 2014, IDF Diabetes Atlas, 6th ed. Brussels, International Diabetes Federation, Belgium.

Jha, A.K., Aubert, R.E., Yao, J., Teagarden, J.R., Epstein, R.S., 2012, Greater Adherence to Diabetes Drugs is linked to Less Hospital Use and Could Save Nearly \$5 Billion Annually, Health Affairs, 31 (8) : 1836-1846.

Notoatmodjo, S., 2010, Metodologi Penelitian Kesehatan, Rineka Cipta, Jakarta.

Perkumpulan Endokrinologi Indonesia, 2011, Konsensus Pengelolaan dan Pencegahan Diabetes Melitus Tipe 2 di Indonesia, PB Perkeni, Jakarta.

Prado-Aguilar, C.A., Martinez, Y.V., Segovia-Bernal, Y., Reyes-Martinez, R., Arias-Ulloa, R., 2009, Performance of Two Questionnaires to Measure Treatment Adherence in Patients with Type-2 Diabetes, BMC Public Health, 9 (38).

Sulistria, Yessy Mardianti., 2013, Tingkat Self Care Pasien Rawat Jalan Diabetes Melitus tipe 2 di Puskesmas Kalirungkut Surabaya, Jurnal Ilmiah Mahasiswa Universitas Surabaya, 2 (2).

Toobert, Toobert DJ, Hampson SE, Glasgow RE., 2000, The Summary of Diabetes Self-care Activities Measure, Diabetes Care, 23 (7) : 943-950.

Zolfaghari M, Mousavifar SA, Pedram S, Haghani H., 2012, The Impact of Nurse Short Message Services and Telephone Follow-ups on Diabetic Adherence : Which One is More Effective?, Journal of Clinical Nursing, 21 : 19221931. 